\title{
Economic profitability analysis of husk tomato (Physalis ixocarpa Brot. ex Hornem.) under different silicon dioxide concentrations
}

\author{
Alafita-Vásquez, Guillermo ${ }^{1}$; Hernández-Barrios, Monserrat ${ }^{1}$; Teoba-Domínguez, Saul ${ }^{1}$; \\ Zulueta-Rodríguez, Ramón $^{1}$; Hernández-Montiel, Luis Guillermo ${ }^{2}$; Alemán-Chávez, Isabel ${ }^{1}$; \\ Lara-Capistrán, Liliana ${ }^{1^{*}}$ \\ 1 Universidad Veracruzana. Facultad de Ciencias Agrícolas. Circuito Universitario Gonzalo Aguirre Beltrán \\ S/N, Zona Universitaria. Xalapa, Veracruz, México. C. P. 91090. \\ 2 Centro de Investigaciones Biológicas del Noroeste, S. C. Calle Instituto Politécnico Nacional No. 195, Col. \\ Playa Palo de Santa Rita Sur, La Paz, Baja California Sur, México. C. P. 23096. \\ * Correspondence: llara_capistran@hotmail.com
}

Gitation: Alafita-Vásquez, G., Hernández-Barrios, M., TeobaDomínguez, S., Zulueta-Rodríguez, R., Hernández-Montiel, L. G. Alemán-Chávez, I. \& Lara-Capistrán, L. (2021) Economic profitability analysis of husk tomato (Physalis ixocarpa Brot. ex Hornem.) under different silicon dioxide concentrations. Agro Productividad. https://doi.org/ 10.32854/ agrop.v14i10.2002

Editor in Chief: Dr. Jorge Cadena Iñiguez

Received: March 15, 2021.

Accepted: September 18, 2021.

Published on-line: November 8, 2021

This work is licensed under a Creative Commons Attribution-NonCommercial 4.0 International license.

\section{ABSTRACT}

Objective: To evaluate the effect of different doses of foliar and soil silicon dioxide fertilization on the economic profitability of husk tomato (Physalis ixocarpa Brot. ex Hornem.) cv. 'Querétaro' cultivation under plastic paddings and macro-tunnel conditions.

Design/methodology/approach: Ten treatments were evaluated at different concentrations of silicon dioxide fertilization on soil and foliar application: T1: Control treatment (T), T2: Fertilization with silicon dioxide 20, 40, $60 \mathrm{~g}$ on soil and 100, 150, and $200 \mathrm{ppm}$ foliar (S20/100F), T3: S20/150F, T4: S20/200F, T5: S40/100F, T6: S40/150F, T7: S40/200F, T8: S60/100F, T9: S60/150F and T10: S60/200, distributed in random blocks. Economic profitability indicators such as Benefit/Cost ratio (B/C), Net Present Value (NPV), and Internal Rate of Return (IRR) were determined.

Results: The research established that the S60/150F treatment was the one with the highest economic profitability because it promoted the highest production per hectare, which was reflected in the NPV (MX $\$$ 336,932.97 pesos), the IRR (77.3\%), and a B/C of MX\$1.16 pesos. Also, treatments S40/200F and S60/100F (where $\mathrm{SiO}_{2}$ was applied) reported positive cash flow, unlike the $\mathrm{T}$.

Limitations of the study/implications: With all research facilities closed due to the COVID-19 pandemic, no evidence related to the contribution of foliar and soil silicon bioassay has been verified.

Findings/conclusions: Using $\mathrm{SiO}_{2}$ leads to a financial appreciable rebound of vital importance to be included in economic studies to facilitate the efficient management of the available capital to establish a crop whose field productivity is profitable for the producers.

Keywords: Benefit/Cost ratio (B/C), Net Present Value (NPV), Internal Rate of Return (IRR), yields.

\section{INTRODUCTION}

In 2019, husk tomato (Physalis philadelphica) production in Mexico was 834,274 t, out of which 160,771 t were produced in Sinaloa, 147,023 $\mathrm{t}$ in Zacatecas, and 88,637 $\mathrm{t}$ in Jalisco. These three states are where the highest national production was recorded (SIAP, 2020a), while in Veracruz 12,311 $\mathrm{t}$ were harvested with a yield of $15.525 \mathrm{t} \cdot \mathrm{ha}^{-1}$ (SIAP, 2020b).
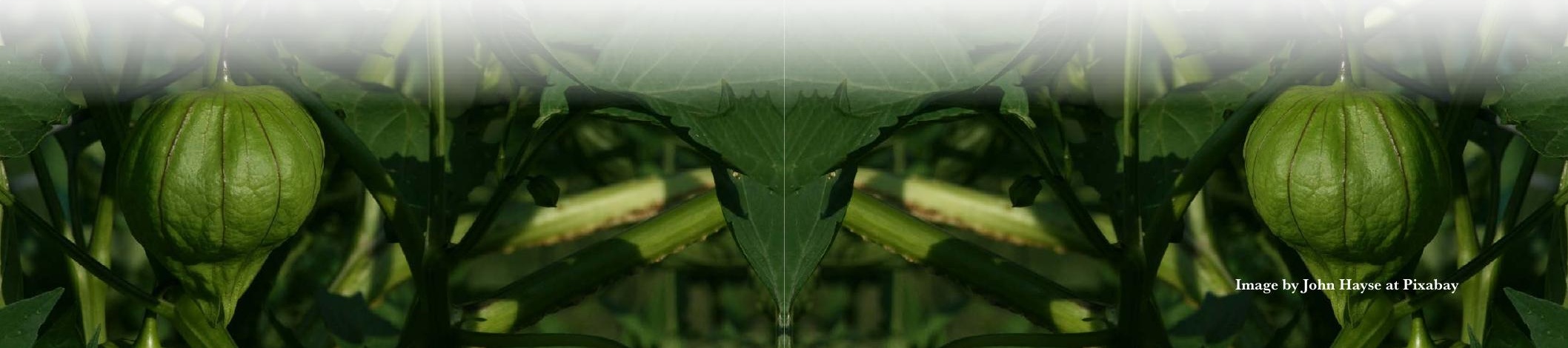
Among the main problems that restrict this crop's field productivity increase is the lack of improved varieties (Peña-Lomelí et al., 2020), phytosanitary problems (Ayala-Armenta et al., 2020), and inadequate agronomic management (López-Ramos et al., 2020). Under protected agriculture conditions, there is greater control of environmental variables compared to open field agriculture conditions (Machorro, 2020). Silicon is a beneficial element for both, open field and greenhouse crops (Tubana et al., 2016; Gómez-Merino et al., 2020) improving growth, development, and production indicators (Asadpour et al., 2020; Bukhari et al., 2020; Shahzad et al., 2021). Silicon is applied to optimize crops profitability beyond the net present value (NPV), payback period (PRI), internal rate of return (IRR), and cost structure, among others. This analysis provides an important point of reference and comparison to assess whether the management implemented for a crop provides adequate returns on the investment made, considering the involved risk (Cano et al., 2013). From such analysis, it is possible to gain certain benefits from the project. The objective of this research was to evaluate the effect different doses of foliar and soil fertilization with silicon dioxide had on the economic profitability of husk tomato (Physalis ixocarpa Brot. ex Hornem.) cv. 'Querétaro' cultivation under plastic paddings and macrotunnel conditions.

\section{MATERIALS AND METHODS}

\section{Location of the experimental area}

The research took place from February to June 2020 in a property near Xalapa, Veracruz state, Mexico, at the geographical coordinates $19^{\circ} 33^{\prime} 05.37^{\prime}$ N, $96^{\circ} 56^{\prime} 40.64$ " $\mathrm{W}$, and 1,428 $\mathrm{m}$ a.s.l. elevation.

The husk tomato crop was established with a drip irrigation system with plastic padding in a macro-tunnel. The production costs and yields of 10 treatments were evaluated and extrapolated to 1 ha, taking into account two production cycles per year. The seeds used were of the cv 'Querétaro' (Optimus Seeds), sown in 200-cavity unicel trays containing peat as substrate $\left(\right.$ COSMOPEAT $\left.^{\circledR}\right)$. Thirty days after sowing (DDS) the seedlings were transplanted to the field, placing them at a $0.4 \mathrm{~m}$ distance between plants and $1.2 \mathrm{~m}$ between rows, with a planting density of 20,833 plants. ha ${ }^{-1}$. The technological package applied in its cultivation was the one recommended by AgroScience (AgroScience ${ }^{\circledR}, 2019$ ).

\section{Treatments and experimental design}

Different doses of silicon dioxide $\left(\mathrm{SiO}_{2}\right)$ applied to the soil $\left(\mathrm{g} \cdot \mathrm{plant}^{-1}\right)$ and foliage $(\mathrm{ppm})$ were evaluated. The doses applied in the soil were 0, 20, 40 and $60 \mathrm{~g} \mathrm{SiO}$ per plant, while the doses applied to the foliage were 100, 150, and $200 \mathrm{ppm} \mathrm{SiO}_{2}$ per plant. There were 10 treatments in total, as described in Table 1.

The experimental design was a completely randomized block. The treatments were distributed in three blocks with 12 plants spaced every $40 \mathrm{~cm}$, in a linear topological arrangement, with a total of 360 experimental units.

\section{Economic profitability analysis}

Production costs were classified into fixed and variable costs, and at the same time, fixed assets, deferred assets, and working capital were considered. Depreciation was calculated 
Table 1. Silicon dioxide $\left(\mathrm{SiO}_{2}\right)$ treatments applied on soil $(\mathrm{S})$ and foliage $(\mathrm{F})$ in husk tomato (Physalis ixocarpa Brot. ex Hornem.) in a microtunnel production system at Xalapa, Veracruz, Mexico.

\begin{tabular}{c|c|c|c}
\hline Treatment & $\begin{array}{c}\text { Application of } \mathbf{S i O}_{\mathbf{2}} \\
\left.\text { to the soil } \mathbf{g}_{\mathbf{~ p l a n t}}{ }^{-\mathbf{1}}\right)\end{array}$ & $\begin{array}{c}\text { Application of } \mathbf{S i O}_{\mathbf{2}} \\
\text { to the foliage (ppm) }\end{array}$ & Key to treatments \\
\hline $\mathrm{T} 1$ & 0 & 0 & $\mathrm{~T} 1(\mathrm{~S} 00 / \mathrm{F} 00)$ \\
\hline $\mathrm{T} 2$ & 20 & 100 & $\mathrm{~T} 2(\mathrm{~S} 20 / \mathrm{F} 100)$ \\
\hline $\mathrm{T} 3$ & 20 & 150 & $\mathrm{~T} 3(\mathrm{~S} 20 / \mathrm{F} 150)$ \\
\hline $\mathrm{T} 4$ & 20 & 200 & $\mathrm{~T} 4(\mathrm{~S} 20 / \mathrm{F} 200)$ \\
\hline $\mathrm{T} 5$ & 40 & 100 & $\mathrm{~T} 5(\mathrm{~S} 40 / \mathrm{F} 100)$ \\
\hline $\mathrm{T} 6$ & 40 & 150 & $\mathrm{~T} 6(\mathrm{~S} 40 / \mathrm{F} 150)$ \\
\hline $\mathrm{T} 7$ & 40 & 200 & $\mathrm{~T} 7(\mathrm{~S} 40 / \mathrm{F} 200)$ \\
\hline $\mathrm{T} 8$ & 60 & 100 & $\mathrm{~T} 8(\mathrm{~S} 60 / \mathrm{F} 100)$ \\
\hline $\mathrm{T} 9$ & 60 & 150 & $\mathrm{~T} 9(\mathrm{~S} 60 / \mathrm{F} 150)$ \\
\hline $\mathrm{T} 10$ & 60 & 200 & $\mathrm{~T} 10(\mathrm{~S} 60 / \mathrm{F} 200)$ \\
\hline
\end{tabular}

T1: Control (without silicon dioxide), T2: Application of $20 \mathrm{~g}$ of $\mathrm{SiO}_{2}$ on soil and $100 \mathrm{ppm}$ of $\mathrm{SiO}_{2}$ sprayed on foliage, T3: Application of $20 \mathrm{~g}$ of $\mathrm{SiO}_{2}$ on soil and $150 \mathrm{ppm}$ of $\mathrm{SiO}_{2}$ sprayed on foliage, T4: Application of $20 \mathrm{~g}$ of $\mathrm{SiO}_{2}$ on soil and $200 \mathrm{ppm}$ of $\mathrm{SiO}_{2}$ sprayed on foliage, T5: Application of $40 \mathrm{~g}$ of $\mathrm{SiO}_{2}$ on soil and $100 \mathrm{ppm}$ of $\mathrm{SiO}_{2}$ sprayed on foliage, T6: Application of $40 \mathrm{~g}$ of $\mathrm{SiO}_{2}$ on soil and $150 \mathrm{ppm}$ of $\mathrm{SiO}_{2}$ sprayed on foliage, T7: Application of $40 \mathrm{~g}$ of $\mathrm{SiO}_{2}$ on soil and $200 \mathrm{ppm}$ of $\mathrm{SiO}_{2}$ sprayed on foliage, T8: Application of $60 \mathrm{~g}$ of $\mathrm{SiO}_{2}$ on soil and $100 \mathrm{ppm}$ of $\mathrm{SiO}_{2}$ sprayed on foliage, T9: Application of $60 \mathrm{~g}$ of $\mathrm{SiO}_{2}$ on soil and $150 \mathrm{ppm}$ of $\mathrm{SiO}_{2}$ sprayed on foliage, T10. Application of $60 \mathrm{~g}$ of $\mathrm{SiO}_{2}$ on soil and $200 \mathrm{ppm}$ of $\mathrm{SiO}_{2}$ sprayed on foliage.

using a linear method, yield and costs were projected to 1 ha area, calculating a fiveyear production period in the same area unit, based on this, the following indicators were estimated:

Cost/benefit ratio $(\mathrm{C} / \mathrm{B})$ : this indicator allows valuing investments, considering economic, social and environmental aspects that are considered in the purely financial evaluation (Arévalo et al., 2016). Net present value (NPV): This refers to the monetary value resulting from subtracting the sum of the discounted cash flows from the initial investment (Fajardo et al., 2019). Internal rate of return or internal return rate (IRR): This is the rate that makes the NPV equal to zero (Fajardo et al., 2019), knowing that this does not mean the nonexistence of benefits, but that these are barely enough to cover the project's expectations (Mete, 2014). The above-mentioned indicators were determined with the Office software using the Excel program, based on the analysis of the costs of inputs that were used in the production, the generated income based on the yields per treatment, the rest of the production costs, and the depreciation of the assets.

\section{RESULTS AND DISGUSSION}

The highest yield $\left(43.8 \mathrm{t} \cdot \mathrm{ha}^{-1}\right)$ was achieved in the S60/150F treatment (T9), which is above the previously reported in 2019 for husk tomatoes $\left(22.75 \mathrm{t}^{\cdot \mathrm{ha}^{-1}}\right)$ grown in irrigated systems (FIRA, 2020). Similarly, the remaining treatments exceeded both, the tonnage referred by the FIRA and that of plants without silicon dioxide $\left(\mathrm{SiO}_{2}\right)(\mathrm{T} 1, \mathrm{~S} 00 /$ F00) (Table 2). 
Table 2. Yield per plant and unit area of husk tomato fruits (Physalis ixocarpa Brot. ex Hornem.) as a response to silicon dioxide $\left(\mathrm{SiO}_{2}\right)$ applications on soil $(\mathrm{S})$ and the foliage $(\mathrm{F})$ in a microtunnel production system at Xalapa, Veracruz, Mexico.

\begin{tabular}{|c|c|c|}
\hline Treatment & Yield $\left(\mathrm{kg} \mathrm{plant}^{-1}\right)$ & Yield $\left(t\right.$ plant $\left.^{-1}\right)$ \\
\hline $\mathrm{T} 1(\mathrm{~S} 00 / \mathrm{F} 00)$ & 0.558 & 15.5 \\
\hline $\mathrm{T} 2$ (S20/F100) & 1.007 & 27.7 \\
\hline T3 (S20/F150) & 1.474 & 40.9 \\
\hline T4 (S20/F200) & 1.138 & 31.6 \\
\hline T5 (S40/F100) & 0.971 & 26.9 \\
\hline T6 (S40/F150) & 1.052 & 29.2 \\
\hline T7 (S40/F200) & 1.365 & 37.9 \\
\hline T8 (S60/100) & 1.522 & 42.2 \\
\hline T9 (S60/F150) & 1.580 & 43.8 \\
\hline T10 (S60/F200) & 1.184 & 32.8 \\
\hline
\end{tabular}

T1: Control (without silicon dioxide), T2: Application of $20 \mathrm{~g}$ of $\mathrm{SiO}_{2}$ on soil and $100 \mathrm{ppm}$ of $\mathrm{SiO}_{2}$ sprayed on foliage, T3: Application of $20 \mathrm{~g}$ of $\mathrm{SiO}_{2}$ on soil and $150 \mathrm{ppm}$ of $\mathrm{SiO}_{2}$ sprayed on foliage, T4: Application of $20 \mathrm{~g}$ of $\mathrm{SiO}_{2}$ on soil and $200 \mathrm{ppm}$ of $\mathrm{SiO}_{2}$ sprayed on foliage, T5: Application of $40 \mathrm{~g}$ of $\mathrm{SiO}_{2}$ on soil and $100 \mathrm{ppm}$ of $\mathrm{SiO}_{2}$ sprayed on foliage, T6: Application of $40 \mathrm{~g}$ of $\mathrm{SiO}_{2}$ on soil and $150 \mathrm{ppm}$ of $\mathrm{SiO}_{2}$ sprayed on foliage; T7: Application of $40 \mathrm{~g}$ of $\mathrm{SiO}_{2}$ on soil and $200 \mathrm{ppm}$ of $\mathrm{SiO}_{2}$ sprayed on foliage, T8: Application of $60 \mathrm{~g}$ of $\mathrm{SiO}_{2}$ on soil and $100 \mathrm{ppm}$ of $\mathrm{SiO}_{2}$ sprayed on foliage, T9: Application of $60 \mathrm{~g}$ of $\mathrm{SiO}_{2}$ on soil and $150 \mathrm{ppm}$ of $\mathrm{SiO}_{2}$ sprayed on foliage, T10. Application of $60 \mathrm{~g}$ of $\mathrm{SiO}_{2}$ on soil and $200 \mathrm{ppm}$ of $\mathrm{SiO}_{2}$ sprayed on foliage.

The exogenous application of silicon improves plant performance due to its participation in regulating proteins related to photosynthesis, photosynthetic pigments, increasing nutrient uptake, and activating antioxidant defense systems in plant cells (Liu et al., 2019; Abdelaal et al., 2020). The basic total cost of production represents the total amount of fixed and variable costs that were required in each treatment and is not affected by costs derived from procurement, silicon application, or direct harvesting and packing costs. This variable includes costs that were the same for all treatments: MX \$269,172.00 (Table 3).

Table 3. Variable and fixed costs of husk tomato (Physalis ixocarpa Brot. ex Hornem.) cultivation in the control (T1) in a microtunnel production system at Xalapa, Veracruz, Mexico.

\begin{tabular}{l|c|c|c}
\multicolumn{1}{c|}{ Variable Costs } & Amount $(\mathbf{M X} \mathbf{\$})$ & Fixed Costs & Amount $(\mathbf{M X \$ )}$ \\
\hline Insecticides and fungicides & $\$ 28,188$ & Renta de terreno & $\$ 15,000$ \\
\hline Fertilizers* & $\$ 49,684$ & Renta de tractor & $\$ 2,000$ \\
\hline Herbicides & $\$ 1,400$ & Servicios & \\
\hline Seedlings & $\$ 122,500$ & & \\
\cline { 1 - 2 } Wooden box and plastic padding & $\$ 8,700$ & & \\
\cline { 1 - 2 } Land workers & $\$ 15,000$ & & \\
\cline { 1 - 2 } Temporary landworkers & $\$ 19,800$ & & \\
\hline Total costs & $\$ 245,272$ & Total costs & $\$ 43,700.00$ \\
\hline
\end{tabular}

* The cost changes depending on each treatment. Costs in Mexican pesos as of June 2020. 
Table 4 shows the variation in costs depending on the silicon concentration of each treatment and the yield obtained in each one.

Labor represents the highest expenditure percentage in the costs of production, which, according to the $\mathrm{SiO}_{2}$ applied dose, was around 33.07\%, depending on each treatment's yield. This coincides with the results obtained in other assessments of the economic profitability, such as the one by Ayala et al. (2014) in amaranth (Amaranthus spp.) cultivation at the central region of Mexico, which influenced jobs generation and prevented migration.

Villa and Barrientos (2012) reported a costs production increase in creole potato (Solanum tuberosum Andigena group) crops per unit area due to manganese application, which increased yields and demanded more labor for harvesting and packaging, as well as the direct and indirect costs of using this micronutrient.

It is important to note that in this research, the use of silicon increased yields above the average reported for Veracruz by both $\operatorname{SIAP}\left(15.525 \mathrm{t} \cdot \mathrm{ha}^{-1}\right)(\mathrm{SIAP}, 2020 \mathrm{~b})$ and FIRA $\left(22.75 \mathrm{t} \cdot \mathrm{ha}^{-1}\right)$ (FIRA, 2020) (Table 2).

Assets costs were classified as fixed, variable, and working capital (Table 3). Regard the concept of fixed cost, Baca (2010) states that they are those done by the company and that in short term, or for certain production levels, do not depend on the production volume. The total cost of the assets was MX $\$ 57,042.00$, with the irrigation system accounting for $70 \%$ of the total. All fixed assets were depreciated using the straight-line method with a useful life of five years, which is the estimated time of the project.

For the scale, a salvage value of MX $\$ 1,197.50$ pesos was achieved, since its useful life is of 10 years, unlike the rest of the fixed assets whose useful life is equal to or less than five

Table 4. Costs increase by silicon dioxide $\left(\mathrm{SiO}_{2}\right)$ application per year of production in a hectare of husk tomato (Physalis ixocarpa Brot. ex Hornem.) in the Control (T1) in a microtunnel production system at Xalapa, Veracruz, Mexico.

\begin{tabular}{c|c|c|c}
\hline Treatments & $\mathbf{S i O}_{2}$ (Cost) & Land workers & Wooden box \\
\hline $\mathrm{T} 1(\mathrm{~S} 00 / \mathrm{F} 00)$ & $\$ 0.00$ & $\$ 19,000$ & $\$ 62,080$ \\
\hline $\mathrm{T} 2(\mathrm{~S} 20 / \mathrm{F} 100)$ & $\$ 600$ & $\$ 35,400$ & $\$ 111,600$ \\
\hline $\mathrm{T} 3(\mathrm{~S} 20 / \mathrm{F} 150)$ & $\$ 600$ & $\$ 40,500$ & $\$ 126,120$ \\
\hline $\mathrm{T} 4(\mathrm{~S} 20 / \mathrm{F} 200)$ & $\$ 600$ & $\$ 40,500$ & $\$ 126,120$ \\
\hline $\mathrm{T} 5(\mathrm{~S} 40 / \mathrm{F} 100)$ & $\$ 600$ & $\$ 33,900$ & $\$ 107,600$ \\
\hline $\mathrm{T} 6(\mathrm{~S} 40 / \mathrm{F} 150)$ & $\$ 600$ & $\$ 33,200$ & $\$ 116,560$ \\
\hline $\mathrm{T} 7(\mathrm{~S} 40 / \mathrm{F} 200)$ & $\$ 1,200$ & $\$ 48,000$ & $\$ 151,240$ \\
\hline $\mathrm{T} 8(\mathrm{~S} 60 / 100)$ & $\$ 1,200$ & $\$ 54,600$ & $\$ 171,960$ \\
\hline $\mathrm{T} 9(\mathrm{~S} 60 / \mathrm{F} 150)$ & $\$ 1,200$ & $\$ 55,500$ & $\$ 175,040$ \\
\hline $\mathrm{T} 10(\mathrm{~S} 60 / \mathrm{F} 200)$ & $\$ 1,200$ & $\$ 41700$ & $\$ 131,000$ \\
\hline
\end{tabular}

T1: Control (without silicon dioxide), T2: Application of $20 \mathrm{~g}$ of $\mathrm{SiO}_{2}$ on soil and $100 \mathrm{ppm}$ of $\mathrm{SiO}_{2}$ sprayed on foliage, T3: Application of $20 \mathrm{~g}$ of $\mathrm{SiO}_{2}$ on soil and $150 \mathrm{ppm}$ of $\mathrm{SiO}_{2}$ sprayed on foliage, T4: Application of $20 \mathrm{~g}$ of $\mathrm{SiO}_{2}$ on soil and $200 \mathrm{ppm}$ of $\mathrm{SiO}_{2}$ sprayed on foliage, T5: Application of $40 \mathrm{~g}$ of $\mathrm{SiO}_{2}$ on soil and $100 \mathrm{ppm}$ of $\mathrm{SiO}_{2}$ sprayed on foliage, T6: Application of $40 \mathrm{~g}$ of $\mathrm{SiO}_{2}$ on soil and $150 \mathrm{ppm}$ of $\mathrm{SiO}_{2}$ sprayed on foliage, T7: Application of $40 \mathrm{~g}$ of $\mathrm{SiO}_{2}$ on soil and $200 \mathrm{ppm}$ of $\mathrm{SiO}_{2}$ sprayed on foliage, T8: Application of $60 \mathrm{~g}$ of $\mathrm{SiO}_{2}$ on soil and $100 \mathrm{ppm}$ of $\mathrm{SiO}_{2}$ sprayed on foliage, T9: Application of $60 \mathrm{~g}$ of $\mathrm{SiO}_{2}$ on soil and $150 \mathrm{ppm}$ of $\mathrm{SiO}_{2}$ sprayed on foliage, T10. Application of $60 \mathrm{~g}$ of $\mathrm{SiO}_{2}$ on soil and $200 \mathrm{ppm}$ of $\mathrm{SiO}_{2}$ sprayed on foliage. Costs in Mexican pesos (MX\$) as of June 2020. 
years. Working capital was estimated at MX $\$ 173,294.67$ pesos. The total income for the five years of the project was restated at a $20 \%$ rate, as shown in Table 5.

Also, for the project purposes, the selling price recorded by the producer was MX $\$ 9.00$ pesos according to the fruit and vegetable marketing margins reported by the FIRA (2020) for peel tomato for October 2020, giving a total of MX\$9,000.00 pesos per ton of fruit. Although the highest yield treatment, and therefore the one with the highest income was T9 (S60/150F), all treatments reported higher cash flows than that of the control.

The NPV of the treatment with the highest income (T9) was MX \$ 336,932.97 pesos, which indicates the gains with regard to the initial investment amount (Table 5) at a discount rate of $20 \%$. Thus, and according to this indicator criteria, the project is profitable, considering that an NPV of less than zero indicates that the project is not.

The economic IRR of a project is the discount rate that makes the present value of the stream of benefits equal to the present value of the stream of costs (Baca, 2010). Then, the IRR for this treatment was $77.3 \%$ and is acceptable since it is higher than the expected return rate $(20 \%)$, so that during the useful life of the project, for each invested peso, a profit of 0.16 Mexican pesos will be obtained $(\mathrm{B} / \mathrm{C}=\mathrm{MX} \$ 1.16)$, so that this treatment does not support a price lower than MX\$8,000.00 pesos per ton of fruit.

Table 5 shows that treatments T9 and T8, where high doses of silicon (S60/150F and S60/100F) were used, positive cash flows are obtained. These results concur with those by Mejía and Lopez (2019), who indicate that by applying Si in high doses on King Grass texas-25 (Pennisetum purpureum), the gain is higher compared to the absolute control.

Table 5. Total updated income and expenses for each treatment projected to five years, and calculation of NPV, IRR and B/C in different treatments with silicon dioxide $\left(\mathrm{SiO}_{2}\right)$ in husk tomato (Physalis ixocarpa Brot. ex Hornem.) cultivation in a microtunnel production system at Xalapa, Veracruz, Mexico.

\begin{tabular}{|c|c|c|c|c|c|c|c|c|}
\hline Treatments & Income $(\$)$ & Expenses (\$) & $\begin{array}{c}\text { Cash Flow } \\
(\$)\end{array}$ & $\begin{array}{c}\text { Updated } \\
\text { income }(\$)\end{array}$ & $\begin{array}{c}\text { Updated } \\
\text { expenses }(\$)\end{array}$ & NPV (\$) & $\operatorname{IRR}(\%)$ & $\mathbf{B} / \mathbf{C}(\$)$ \\
\hline $\mathrm{T} 1$ & $1,436,646$ & $2,493,476$ & $2,493,476$ & 856,670 & $1,554,573$ & $-697,903.71$ & $\%^{¥}$ & 0.55 \\
\hline $\mathrm{T} 2$ & $2,582,443$ & $2,867,811$ & 285,368 & $1,540,092$ & $1,784,655$ & $-244,563.00$ & $\%^{¥}$ & 0.86 \\
\hline T3 & $2,918,235$ & $2,979,565$ & $-61,329$ & $1,740,379$ & $1,853,343$ & $-112,964.32$ & -13.3 & 0.94 \\
\hline $\mathrm{T} 4$ & $2,918,235$ & $2,979,565$ & 61,329 & $1,740,379$ & $1,853,343$ & $-112,964.32$ & -13.3 & 0.94 \\
\hline T5 & $2,490,164$ & $2,836,484$ & 346,319 & $1,485,051$ & $1,765,400$ & $-280,348.57$ & $\%^{¥}$ & 0.84 \\
\hline T6 & $2,697,791$ & $2,906,315$ & 208,524 & $1,608,893$ & $1,808,321$ & $-199,428.44$ & $\%^{¥}$ & 0.89 \\
\hline $\mathrm{T} 7$ & $3,500,105$ & $3,168,783$ & 331,322 & $2,087,441$ & $1,969,644$ & $117,796.88$ & 43.1 & 1.06 \\
\hline T8 & $3,979,443$ & $3,324,395$ & 655,047 & $2,373,347$ & $2,065,290$ & $308,057.25$ & 73.2 & 1.15 \\
\hline T9 & $4,051,215$ & $3,347,064$ & 704,150 & $2,416,156$ & $2,079,223$ & $336,932.97$ & 77.3 & 1.16 \\
\hline $\mathrm{T} 10$ & $3,036,147$ & $3,018,753$ & 17,394 & $1,810,708$ & $1,877,429$ & $-66,720.95$ & 3.1 & 0.96 \\
\hline
\end{tabular}

T1: Control (without silicon dioxide); T2: Application of $20 \mathrm{~g}$ of $\mathrm{SiO}_{2}$ on soil and $100 \mathrm{ppm}$ of $\mathrm{SiO}_{2}$ sprayed on foliage, T3: Application of 20 $\mathrm{g}$ of $\mathrm{SiO}_{2}$ on soil and $150 \mathrm{ppm}$ of $\mathrm{SiO}_{2}$ sprayed on foliage, T4: Application of $20 \mathrm{~g}$ of $\mathrm{SiO}_{2}$ on soil and $200 \mathrm{ppm}$ of $\mathrm{SiO}_{2}$ sprayed on foliage, T5: Application of $40 \mathrm{~g}$ of $\mathrm{SiO}_{2}$ on soil and $100 \mathrm{ppm}$ of $\mathrm{SiO}_{2}$ sprayed on foliage, T6: Application of $40 \mathrm{~g}$ of $\mathrm{SiO}_{2}$ on $\mathrm{soil}_{\text {and }} 150 \mathrm{ppm}$ of $\mathrm{SiO} 2$ sprayed on foliage, T7: Application of $40 \mathrm{~g}$ of $\mathrm{SiO}_{2}$ on soil and $200 \mathrm{ppm}$ of $\mathrm{SiO}_{2}$ sprayed on foliage, T8: Application of $60 \mathrm{~g}$ of $\mathrm{SiO} 2$ on soil and $100 \mathrm{ppm}$ of $\mathrm{SiO}_{2}$ sprayed on foliage, T9: Application of $60 \mathrm{~g}$ of $\mathrm{SiO}_{2}$ on soil and $150 \mathrm{ppm}$ of $\mathrm{SiO}_{2}$ sprayed on foliage, T10. Application of $60 \mathrm{~g}$ of $\mathrm{SiO}_{2}$ on soil and $200 \mathrm{ppm}$ of $\mathrm{SiO}_{2}$ sprayed on foliage.

Benefit / cost ratio $(\mathrm{B} / \mathrm{C})$; Net present value (NPV); Internal rate of return (IRR).

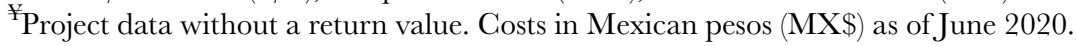




\section{CONGLUSIONS}

Product price and yield per hectare represent the main factors affecting the economic profitability of treatments applied to crops. In our research, the best treatment was T9 (S60/150F), reporting a higher cash flow than that of the control treatment. Also, because the present research only considered one price per kilogram of husk tomato, without considering quality variables that could contribute to the commercialization of the fruit of this Solanaceae in specific markets at higher prices, it is recommended to continue with the economic evaluation for several cycles, to corroborate the yield data per treatment and therefore compare the results obtained in the present results.

\section{ACKNOWLEDGMENTS}

The authors would like to thank our university authorities for the financial support given to the students of the Protected Agriculture IV elective course of the Facultad de Ciencias Agrícolas. Also, to Anadely CabreraGonzález, Saúl Cuevas-Presa and Ezequiel Castillo-Parra for their participation in this research.

\section{REFERENGES}

Abdelaal, K.A., Mazrou, Y.S., Hafez, Y.M. (2020). Silicon foliar application mitigates salt stress in sweet pepper plants by enhancing water status, photosynthesis, antioxidant enzyme activity and fruit yield. Plants 9 , (6). 733. doi:10.3390/plants9060733

AgroScience ${ }^{\circledR}$. (2019). Paquete de nutrición para tomatillo. Disponible en: https://www.agroscience.com.mx

Arévalo B., K., Pastrano Q., E., Armijos J., V. (2016). Relación beneficio-costo por tratamiento en la producción orgánica de las hortalizas (cilantro, lechuga, cebolla roja, cebolla de rama) en el cantón Santo Domingo de Los Colorados. Revista Publicando 3(7), 503-528.

Asadpour, S., Madan, H., Mohammadi, G.N., Hearvan, I.M., Abad, H.H.S. (2020). Improving maize yield with advancing planting time and nano-silicon foliar spray alone or combined with zinc. Silicon 2020. Doi: 10.1007/s12633-020-00815-5.

Ayala-Armenta, Q.A., Tovar-Pedraza, J.M., Apodaca-Sánchez, M.A., Correia, K.C., Sauceda-Acosta, C.P., Camacho-Tapia, M., Beltrán-Peña, H. (2020). Phylogeny and pathogenicity of soilborne fungi associated with wilt disease complex of tomatillo (Physalis ixocarpa) in northern Sinaloa, Mexico. European Journal of Plant Pathology 157, 733-749. Doi: 10.1007/s10658-020-02030-9

Ayala G., A.V., Rivas-Valencia, P., Cortes-Espinoza, L., de la O. Olán, M., Escobedo-López, D., EspitiaRangel, E. (2014). La rentabilidad del cultivo de amaranto (Amaranthus spp.) en la región centro de México. CIENCIA Ergo Sum 21(1), 47-54.

Baca U., G. (2010). Evaluación de Proyectos. (6ª Edición). Mc Graw Hill, México.

Bukhari, M.A., Ahmad, Z. Ashraf, M.Y., Afzal, M., Nawaz, F., Nafees, M., Jatoi, W.N., Malghani, N.A., Shah, A., Manan A. (2020). Silicon mitigates drought stress in wheat (Triticum aestivum L.) through improvising photosynthetic pigments, biochemical and yield characters. Silicon 2020. Doi: 10.1007/ s12633-020-00797-4.

Cano F., M., Olivera G., D.A., Balderrabano B., J., Pérez C., G. (2013). Rentabilidad y competitividad en la PYME. Revista Ciencia Administrativa, 2013(2): 80-86.

Fajardo V., L.M., Girón G., M.F., Vásquez F., G.E., Fajardo V., L.A., Zúñiga S., X.L., Solis G., L.E., Pérez S., J.A. (2019). Valor actual neto y tasa interna de retorno como inversiones de evaluación para los inversores. Revista Investigación Operacional 40(4), 469-474.

FIRA (Fideicomisos Instituidos en Relación con la Agricultura) (2020). Tomate verde mercado nacional. Información sectorial. Disponible en: https:/www.fira.gob.mx/InvYEvalEcon/EvaluacionIF

Gómez-Merino, F.G., Trejo-Téllez, L.I., García-Jiménez, A., Escobar-Sepúlveda, H.F., Ramírez-Olvera, S.M. (2020). Silicon flow from root to shoot in pepper: A comprehensive in silico analysis reveals a potential linkage between gene expression and hormone signaling that stimulates plant growth and metabolism. PeerJ 8. 10053. https://doi.org/10.7717/peerj. 10053.

Liu, B., Soundararajan, P., Manivannan, A. (2019). Mechanisms of silicon-mediated amelioration of salt stress in plants. Plants 8, (9). 307. doi:10.3390/plants8090307 
Machorro,J.C. (2020). Agricultura protegida, alternativa mexicana para frenar el cambio climático. Disponible en: https://www.lavanguardia.com/vida/20200130/473219700011/agricultura-protegida-alternativamexicana-para-frenar-al-cambio-climatico.html

Mejía C., H.J., López G., F.E. (2019). Utilización del silicio como promotor de crecimiento del pasto King Grass Texas-25 para la generación de bioenergía. Revista Iberoamericana de Bioeconomía y Cambio Climático 5(9), 1144-1156. Doi: 10.5377/ribcc.v5i9.7950

Mete, M.R. (2014). Valor actual neto y tasa de retorno: Su utilidad como herramienta para el análisis y evaluación de proyectos de einversión. Fidese et Ratio 7 (7), 67-85.

Peña-Lomelí, A., Ríos-Hernández, N.E., Santos-Moreno, O., Magaña-Lira, N. (2020). Parámetros genéticos de la población Gema de tomate de cáscara (Physalis ixocarpa Brot. ex Horm.). Revista Chapingo Serie Horticultura 26(2), 83-94.

Tubana, B.S., Babu, T., Datnoff, L.E. (2016). A review of silicon in soils and plants and its role in US agriculture: History and future perspectives. Soil Science 181(9/10), 393-411. Doi: 10.1097/SS.0000000000000179

Shahzad, S., Ali, S., Ahmad, R., Ercisli, S., Anjum, M.A. (2021). Foliar application of silicon enhances growth, flower yield, quality and postharvest life of tuberose (Polianthes tuberosa L.) under saline conditions by improving antioxidant defense mechanism. Silicon 2021. Doi: 10.1007/s12633-021-00974-z

SIAP Servicio de Información Agrícola y Pecuario) (2020). Tomate verde. Panorama agroalimentario 2020. SIAP, México. Disponible en: https://www.inforural.com. mx/wp-content/uploads/2020/11/AtlasAgroalimentario-2020.pdf

SIAP (Servicio de Información Agrícola y Pecuario) (2020). Avance de siembras y cosechas (otoño-invierno 2020, Riego+Temporal); Resumen por cultivo: Veracruz. Disponible en: http://infosiap.siap.gob. mx:8080/agricola_siap_gobmx/ResumenDelegacion.do

Trópicos/Missouri Botanical Garden (2021). Physalis ixocarpa Brot. ex Hornem.; Accepted names. Disponible en: http://legacy.tropicos.org/Name/ 29602557?tab=acceptednames\&langid=66

Villa, M.R., Barrientos, J.C. (2012). Incremento de la rentabilidad económica en el cultivo de papa criolla mediante fertilización con manganeso. Revista Colombiana de Ciencias Hortícolas 6(1), 67-75. Doi: 10.17584/rcch.2012v6il.1282. 